\title{
Incidence of Escherichia coli $\beta$ - Glucuronidase Positive on Goat Milk
}

\author{
Zorica VOŞGAN*, Anca DUMUȚA, Stela JELEA, Lucia MIHALESCU, Flavia POP \\ ${ }^{1}$ Technical University of Cluj-Napoca, North University Center of Baia Mare, Romania \\ *corresponding author: zori_v13@yahoo.com
}

Bulletin UASVM series Agriculture 73(2)/2016

Print ISSN 1843-5246; Electronic ISSN 1843-5386

DOI 10.15835/buasvmcn-agr: 12428

\begin{abstract}
Papers on beta- glucuronidase sensitivity and specificity for identifying Escherichia coli in sources of environment, food, water, etc. have been published since 1976. In this study we conducted a review of the incidence of $E$. coli $\beta$ - glucuronidase -positive in goat milk, obtained by hand milking throughout the lactation: spring, summer, autumn. The presence of $E$. coli in milk is considered both as a health indicator and a pathogenic factor capable of causing food poisoning. The determination of the $E$. coli $\beta$-glucuronidase-positive was carried using TBX medium by cultivating colonies typical blue at $44^{\circ} \mathrm{C}$. The absence of $E$. coli in milk yielded during the spring, when the animal milking is done three times a day, was found in the performed analyses; the same was observed during fall, when the milk production is lower and the milking is done once a day. The load of $E$. coli $\beta$-glucuronidase-positive was averaging $66.67 \mathrm{CFU} / \mathrm{ml}$ of goat milk, during the middle lactation period (July-August), in conditions of higher temperature. During this period, milking is done in the mountain zone, where the transhumance of animals takes place in summer. The presence of the species E. coli was also confirmed by microscopic examination. Attention should be paid to hygiene and milk should be immediately cooled, during hot weather, as E. coli can be a source of food poisoning.
\end{abstract}

Keywords: Escherichia coli, hygiene, milk.

Introduction. Milk is an excellent growing environment for microorganisms. Escherichia coli is one of pathogens that can multiply in milk, if it has been produced in unsanitary conditions and it has not been immediately cooled (Barzoi and Apostu, 2002). The existence of some serotypes of $E$. coli in goat milk has been reported over time by many authors, (Foschino et al., 2002; Muehlherr et al., 2003; Bhekisisa and Buys, 2009; Cupáková et al. 2012), but its sensitivity to a lot of antimicrobials is known. Kilian and Bulow (1976), described the association of beta-glucuronidase with the genus Escherichia and suggested that a beta-glucuronidase assay would be a useful identification test (Rice et al., 1990).

Aims and objectives. The aim of this study is to detect E. coli strains b - glucuronidase positive - in samples of collected goat milk, depending on the lactation period. The objectives of this study have been the detection and counting of colony forming units which contaminate food.

Materials and methods. Milk samples were collected by hand milking from 50-60 goats that had been raised and maintained in traditional system. Milk samples were collected in spring, when goats milking is done three times a day; in summer, when milking is done twice a day and during fall when milking is done once a day. Method of working used is based on ISO 16649-2:2001 and describes the enumeration of $\beta$-Glucuronidase positive E.coli in food and dairy products by pour plate. This method uses a colony count technique at $44^{\circ} \mathrm{C}$ with a solid medium (TBX).

Results and Discussion. In milk and dairy products the types of Enterobacteriaceae positive lactase generally predominate, causal of human food poisoning. The hygiene conditions in the rooms where animals are milked, the objects used for milking, the milkman, as well as water used in the cleaning process can influence the 
food contamination degree. Also, the variation of the environmental factors is highly important for the quality and healthiness of foodstuffs as, under favourable multiplying conditions, microorganisms act and devalue food. The way in which the conditions in the mountain zone during summertime allowed the growth and multiplication of the E. coli strain was observed in this research. No presence of E. coli $\beta$ - glucuronidase-positive was detected during springtime, when the animals are kept within the local community under the farmer's shelter and the production of dairy is high.

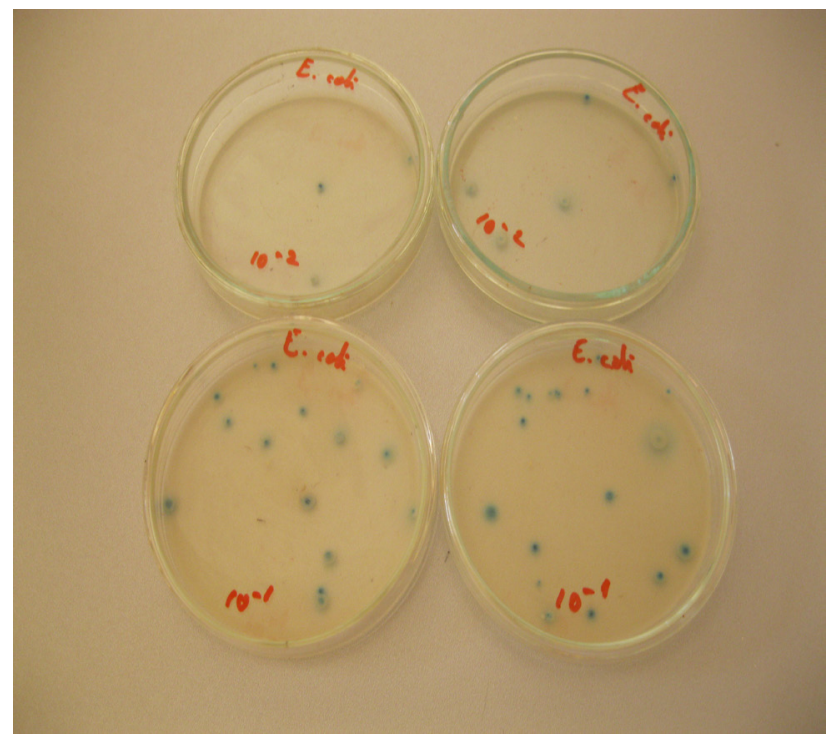

Fig. 1. Macroscopic features of the Petri dishes in the presence of Escherichia coli b - glucuronidase positive, during summer

E. coli $\beta$-glucuronidase-positive was detected in summertime (Fig.1), during the transhumance of animals in the mountains, when the access to the area is difficult in terms of ensuring proper sanitation conditions. The average values recorded in terms of determining $E$. coli $\beta$-glucuronidasepositive were $66.67 \mathrm{CFU} / \mathrm{ml}$ of goat milk, during the middle lactation period (July-August), in conditions of higher temperature. The presence of the species E. coli was also confirmed by microscopic examination. No specific colony of $E$. coli $\beta$-glucuronidase-positive was identified during autumn, when the flocks return to the local shelter and the milk yield is reduced.

Conclusion. The occurrence of $E$. coli in summer can be explained by a hygiene shortfall, in housing conditions in the mountains; however, one must pay additional attention because it could be a source of food poisoning to consumers. In summer, the recorded average value of such germs in raw milk is below the level of acceptability.

\section{REFERENCES}

1. Bărzoi D, Apostu S (2002). Microbiologia produselor alimentare. Ed. Risoprint, Cluj Napoca.

2. Bhekisisa C, Buys E (2009). Adaptation of Escherichia coli 0157:H7 to acid in traditional and commercial goat milk amasi. Food Microbiology 26(1):58-64.

3. Cupáková Š, Pospišilová M, Karpisková R, Janštová B. Vorlová L (2012). Microbiological quality and safety of goats milk from one farm. Acta Universitatis Agriculturae et Silviculturae Mendelianae Brunensis 60(6): 33-38.

4. Foschino RA, Invernizzi R, Barucco $K$, Stradiotto $K$ (2002). Microbial composition, including the incidence of pathogens, of goat milk from the Bergamo region of Italy during a lactation year. Journal of Dairy Research 69(2):213-225.

5. Kilian M, Bülow $P$ (1976). Rapid diagnosis of Enterobacteriaceae. I. Detection of bacterial glycosidases. Acta Pathol Microbiol Scand B 84B(5):245-251.

6. Muehlherr JE, Zweifel C, Corti S, Blanco JE, Stephan R (2003). Microbiological Quality of Raw Goat's and Ewe's Bulk-Tank Milk in Switzerland. Journal of Dairy Science 86 (12):3849-3856.

7. Rice EW, Allen MJ, Edberg SC (1990). Efficacy of betaglucuronidase assay for identification of Escherichia coli by the defined-substrate technology. Appl Environ Microbiol 56(5): 1203-1205. 